\title{
Ethics and the Non-physical Self in Ndorobo World View
}

\author{
Shelly Ashdown \\ Graduate Institute of Applied Linguistics \\ Dallas, Texas, 75236, USA \\ E-mail: Shelley_ashdown@gial.edu
}

\begin{abstract}
Ethics in Ndorobo world view are concerned primarily with Self and its effect on the welfare and moral state of community Other. Significant psychical elements of Self such as personality, character, honesty, desire, and decision can affect the state of community strength through personal behaviour deemed ethical or unethical. Ndorobo ethics is concerned exclusively with governing social conduct for interpersonal relations. This article proposes that elements of the non-physical Self are sources for moral behaviour, and social customary law is the basis for moral duty among the Ndorobo. Germane to the discussion are the roles associated with the non-physical Self that reflect four basic ethical principles in Ndorobo world view: 1) Ethical principle of social unity; 2) Ethical principle of relational exchange; 3) Ethical principle of respect; and 4) Ethical principle of role standards. Conformity to role expectations by Self is highly valued as an ethical axiom that is viewed as natural and necessary in the life of a Ndorobo.
\end{abstract}

Keywords: Ndorobo, Non-physical self, Ethical principle, Social unity

\section{Introduction}

At the highest levels of academia, ethics is defined as the systematic, philosophical study of morality. A more pragmatic approach recognises ethics as a discipline that investigates the meanings and purposes behind conduct. The concern is with constructing the moral order of a people based on the perceived rightness or wrongness of behaviour. In this way ethics and morality are part of cultural systems which are composed from and transmitted through the socio-cultural context; and further, ethics as a socio-cultural construct serves as an authoritative paradigm for interpersonal behaviour (Bird, 1981). It is the science of duty i.e. moral duty intent on discovering ideals of both character and behaviour (Uka, 1991). The study of ethics seeks to understand the sources for choice in individual 
action whether it be right or wrong and the basis for such action. In this paper, I consider elements of the non-physical Self as sources for moral behaviour, and social customary law as the basis for moral duty among the Ndorobo people of East Africa.

The Maa speaking Ndorobo people inhabiting the southern portion of the Mau Escarpment in Kenya utilise key elements of the non-physical Self to structure basic ethical assumptions. Significant psychical elements of Self such as personality, character, honesty, desire, and decision can affect the state of community vitality through personal behaviour deemed ethical or unethical. Ethics in Ndorobo world view are concerned primarily with the effect of Self on the welfare and moral state of community Other.

\section{Social Construct of Ethics and the Non-physical Self}

Of the four general categories of morality (religious, natural, individual, and social), social morality is the most salient classification across cultures (Thiroux 1977). Self must have a code of conduct for interacting with Other and specifically to govern social relationships. In general the collectivist orientation found in African communities has fostered an ethos with a synthesis of personal, social, and spiritual components albeit with social mandates in a prominent position. Modern Western societies seem to lack a symbiosis of ethos and world view. Indeed, meanings and motivations of a personal nature often have little connection to one's social Self. This dichotomy between personal and social meanings of life often create conflicting moral motivations within the daily life of a Western individual since there is no single ultimate ethical code to act as a guide (Moseley 1979). Traditional African morality entertains no such conflict because Self is conceived to be a natural blend of individuality and community membership role acting in concert with each other. The social concept of moral behaviour is supported by Mbiti's view that:

"the essence of African morality is that it is more 'societary' than 'spiritual'; it is a morality of 'conduct' rather than a morality of 'being'...for it defines what a person does rather than what he is. Conversely, a person is what he is because of what he does, rather than that he does what he does because of what he is" (Mbiti 1990:209).

This emphasis on proper social behaviour underpins the basis of morality among African people groups. Sarpong writes of the Akan, "what a man is is less important than what a man does...a person is what he is because of his deeds. 
He does not perform those deeds because of what he is" (1972:42). Indeed what a person does must go beyond personal, inner Self motivations and reflect communal moral values (Nwagwu 2002).

Ethics in Ndorobo world view are revealed in the elements of the nonphysical Self as the sources of personal action. To Ndorobo the question of ethics relates only to the outward demonstration of individual expression and does not include any notions of an inner condition, simply because that which is inside is simultaneously outside. Ndorobo ethics is a morality of conduct rather than a morality of being by defining what a person does instead of what an individual is. The ethical mandate declares, 'You are Ndorobo. Now act like it!' The meaning and purpose of behaviour is evaluated against one's moral duty as Ndorobo. Non-physical Self elements are the source of Ndorobo mode of conduct regulated by community customs, traditions, and taboos.

The relevance and importance of behaviour in Ndorobo morality is key. To be honest (esipata), for example, a person first must engage his/her non-physical element of esipata and behave honestly. The emphasis is placed on the act. The dishonest person may be held responsible for becoming dishonest because his personality (olkuak) is the result of repeated voluntary acts of dishonesty. The person has the choice between committing dishonest behaviour or refraining from such action. This illustrates the Ndorobo conviction that not only is a person responsible for personal morality, but behaviour is morality.

The rightness or wrongness of an act is measured against community values found in an individual's olkuak (personality). Olkuak is the cultural mandates for behaviour and values the person is expected to assume as their personality. It is the moral ideal in Ndorobo thought giving rise to harmonious integration of the person with the world. Olkuak is a guiding force over Self that aspires toward a quintessential social order in which members of the community live in harmony without quarrelling.

Olkuak is often translated 'personality' but bears little resemblance to the English translation. It is conceived in a radically different mode of thought. Ndorobo view the person as an extension of the community, one pebble in a bucket of sand. One grain is meaningless and easily overlooked; a handful takes form, fills space, and therefore has meaning and use. The personality of the person, their olkuak, submerges Self within the community thereby providing Self with purpose, value, strength and most importantly, a means of appropriate expression.

Abandoning one's olkuak is equivalent to lost knowledge. It is ignoring knowledge of right and wrong by rejecting the moral imperative and values of one's social heritage. This can only be restored by Enkai (divine Creator) through corrective measures that cause a repentant heart. In this way, personality serves as 
conscience. The idea that conscience is 'a complex of residual habits' imposed by society is somewhat descriptive of the Ndorobo notion of conscience (Gbadegesin 1991:68). Olkuak (personality) serves as conscience by issuing the standard of ethics the person measures himself against and as proctor of moral reasoning. The ideas of moral rightness and wrongness are not found in a separate, bounded element but are included in the functional role of personality. Personality is a discerning element, one that determines good and evil. The individual notions of right and wrong which distinguish people from one another in part are the result of what each olkuak has been taught and subsequently accepted.

The source of moral values dictating the behaviour of individuals is not divine commands but rather the cultural demands of Ndorobo community. Elaborate prescriptions guiding the ethical life of each person are given in a coherent system of ethics founded in socially revealed commands and expectations. It is the community not Enkai (divine Creator) who is the source of moral right and wrong definition. The supernatural plays an important role in behaviour but not in terms of constituting the source of moral definition or value. Morality for Ndorobo exists in the social conduct of community members. Moral definition and moral values are actively observed in the social behaviour of a person.

The central focus of Ndorobo morality is a concern for community well being. This social character is intrinsic to the notion of right and wrong since unless society existed, there would be no such thing as proper or improper behaviour. Gyekye comments, "A society-oriented morality is necessarily grounded in human experiences in living together" (1987:145). Such is the understanding of Ndorobo ethics. Consideration for both community well being and social unity is the crucible in which Ndorobo morality is structured, not divine pronouncements. One of the compelling reasons for Ndorobo to pursue right behaviour is to attain individual social acceptance and the benefits of relationships therein. This probably more so than the approval of Enkai (divine Creator).

If utility as Molema (1920) remarked is a contributing factor perhaps in all moral codes, then the ideals of right moral conduct among Ndorobo have the ultimate usefulness for community and individual survival. The Ndorobo measure of right and wrong is custom. Put another way, good is that which receives community approval and bad is that which is disapproved. Right conduct builds community Other along with Self; wrongful behaviour weakens community's structural integrity. Moral behaviour is deemed social while immoral behaviour is judged as antisocial.

Desire (iyieunot) appears to be a focal point in the ethical life of Ndorobo and a crucial element in moral comportment. The Ndorobo recognise the response to moral knowledge is an individual private affair. Having educated and motivated an individual in social morés, a community cannot be guaranteed conformity by 
a person. A person may know and even accept a moral rule but be unable to apply this rule in a particular situation because of uncontrolled desire. Abandoning the Ndorobo ethos is generally attributed to the non-physical element of iyieunot (desire). Personality (olkuak) enables a person to distinguish between that which is good and evil functioning much like a moral sense. But the moral will to carry out the moral directive falls under the responsibility of a person's non-physical element of desire (iyieunot). It is not an inability to apply one's moral sense or moral will that results in immoral expression but a conscious act of disobedience by desire. This suggests that within the Ndorobo conceptual scheme evil stems from free will action by a person based on individual desire.

In the discussion to follow, we consider how the Ndorobo world view reflects basic ethical principles Uka (1991) asserts are common to traditional societies and the role of the non-physical Self in these areas of moral comportment. The first principle is the need by every group to restrain violence. Ndorobo world view addresses this requisite through the ethical code of social unity. Ndorobo use notions of hospitality and reciprocity in relational exchanges for the second axiom to prohibit theft and make contracts a matter of social personality. The third fundamental principle in traditional societies is the value of life which is evidenced in Ndorobo respect for life force. The final topic centers around the need in society to regulate affairs between individuals dependent on role expectations. These kinds of precepts include rules for behaviour in kin relations, between the sexes, and marital fidelity.

\section{Ethical Principle of Social Unity}

The Ndorobo believe a person is born into a particular social group by the will of the divine Creator, Enkai, and is destined to be a product of social forces within that culture. The Ndorobo non-physical Self encompasses elements which join the person and community members together in an integrated fashion. The primary sociocentric element of the person is the non-physical Self component of personality (olkuak). The Ndorobo individual always and necessarily exists as a bearer of olkuak. Self is made continuous with community by olkuak. The initial capacity for personality is given to a newborn by God and content is generated from the social environment. Personality is to be submissive to the will of the collective Other and by doing so olkuak becomes what community makes a person.

The Ndorobo believe personality comes from the actions of the person. It is considered cultural behavioural habits which express features of Ndorobo behaviour expected and shared by members of the community. The individual 
presents themselves to the community by way of olkuak. It is an observable phenomenon and not an abstraction to the Ndorobo psyche. The person is what is observed by others. Either the person has developed a good olkuak and behaves accordingly or has chosen an unsavory personality and shows this by behaviour deemed socially inappropriate. Behaviour is a mirror of an inner state the individual is not capable of hiding or masking.

The Ndorobo morality follows the pattern of traditional societies in that respect for the social rules and norms are indispensable to community unity, peace, continuity, and betterment. Deviant behaviour such as lack of a sense of duty, disregard for elders, and individualism which neglects the in-group is reprimanded as sin against community and the divine. Thus Ndorobo ethics may be interpreted in Durkheimian terms. 'The voice of God' for Ndorobo is actually 'the voice of the people,' that is, the voice of community (1965:37). Malefijt (1989) discounts this as absurd, however I think not. The Ndorobo morality is the will of community set forth in codes of conduct contained in personality and manifested in the behaviour of Self for the ultimate good of both Self and community Other. Social rules endorsed by Enkai (divine Creator) function as sacred rules. Thus Ndorobo ethics is a divinely sanctioned means of preserving Ndorobo society against tribal annihilation caused by disunity.

The Ndorobo inhibit destructive behaviour by insistence on harmony of relationships between Self and community Other. With this customary law, the first universal ethical principle to restrain violence is dealt with in a clear manner. The Ndorobo personality is instrumental in keeping social order through unity of purpose and proper relations conforming to osotuaa (peace or friendship) found in olkuak (personality).

The value the Ndorobo place on social relationships cannot be overstated. Relational unity within the community is not an optional prerogative. Disunity is classified as a cultural sin that is dealt with on the corporate level and must be forgiven by the divine. If allowed to continue, Enkai will judge both the individuals in conflict and community members as a whole. A blessing for reconciliation given after a dispute has been resolved illustrates the importance of maintaining harmony in community relations:

\section{Have a sweet smell!}

Love each other!

Be in unity as part of the community!

May you stand still!

May God agree with what we say!

May you love one another's nose!

Have a long life and do not step on each other! 


\section{Fight for your age-mates to have good fortune! ${ }^{1}$}

Each line of the prayer is stated in the form of a command. A community elder is the speaker charging those in dispute back to a permanent loving relationship under the unifying umbrella of the community. It is necessary to restore love and acceptance between individual community members without the pretence of wavering in order for Enkai to place his blessing on the ceremony. The command to 'stand still' addresses the temptation to act lovingly in the presence of community members and then display contempt in private. Remaining steadfast in thought and deed is characterised as brave; changing from love to scorn is considered cowardly. The charge is to keep relationships united in love by remaining or standing firm in genuine devotion.

The myth, The sacred Mountain of God, is widely known among the Ndorobo and is an important literary work of fiction which dramatically illustrates the devastation caused by social disharmony. ${ }^{2}$ A great drought and famine ravaged the homeland of the Ndorobo leaving the people to question what offence was committed against Enkai. A group of elders were chosen and sent to the Mountain of God to find the cause of the calamities, offer sacrifices, and display sincere repentance.

Once on the mountain, it was learned Enkai was very displeased with the tribe for becoming 'a people of war, clan against clan.' ${ }^{3}$ The misfortune of drought and famine had come upon the people because community members were at enmity with one another. Enkai showed his great mercy by accepting the penance of the elders and admonished the men that the community must live in unity and harmony; if not, famine, sickness, or drought would come again. This pseudo historical account offers insight into moral imperative of social unity. The Ndorobo community demands social harmony in community relationships and uses the weight of divine intervention as a means of ultimate authority validating the moral obligation.

\section{Ethical Principle of Relational Exchange}

In Ndorobo custom, every person is expected to show hospitality and generosity toward community Other. This is embraced with faithful execution since at any time a person may find themselves in a position of need. If these obligations are neglected, the individual cannot expect any consideration in return and neither can offspring. The dependent nature of social relationships for personal and community survival is a powerful motivator toward social morality to benefit Self and kin. 
The social rules of hospitality and reciprocity emphasised by the Ndorobo personality (olkuak) and character (empukunoto) are a social means which indirectly serve as a kind of contractual agreement. Give and take exchanges are not formal, written agreements but a social knowledge of who is indebted to whom for social courtesies leading to favourable consideration of future economic needs. These facilitate business type arrangements needed for economic success.

Proper orientation of Self toward the Ndorobo moral code of relational exchanges is the result of a good, inner personality. Olkuak is a qualification of moral oughts. Nowhere is this more adequately shown than in a narrative depicting a greedy son. ${ }^{4} \mathrm{~A}$ boy working in the fields sees visitors approaching and quickly runs in the house to eat the porridge ready for that morning's breakfast. He begins gulping down the porridge and in his excitement does not realise it is boiling hot. Suddenly his throat is burned, he becomes deaf and faints. Instantly knowing his folly, his mother comes in and curses him.

The son has committed an unpardonable moral breach. Hospitality is the highest value in Ndorobo world view and is defined partially in terms of offering sustenance to visitors. The son's greed was an immoral act quickly resulting in harsh consequences and punishment. His personality chose an iniquitous attitude, prompted him to wrongful behaviour which consequently tortured his physical body. The concept of olkuak creates links whose connectors weave across that which is moral, social, physical and non-physical and, in the process, make the causes in one realm affect others.

The norms of propriety and appropriateness dictated by olkuak require self expression conform to those mandates of hospitality and generosity between members of the Ndorobo community. Olkuak provides individual acceptance and value of prescriptions for relational exchanges and places it in the realm of the social environment. Conformity to personality becomes a moral issue sanctioned by Enkai as a means of coercing members to follow community dictates that proscribe greed and inhospitable behaviour.

\section{Ethical Principle of Respect}

The equal value placed on every soul (enkishui) ${ }^{5}$ upholds the high respect for the sanctity of human life among the Ndorobo. Honoring the gift of life by Enkai is to protect one's own enkishui and respect the soul of others, be it insiders or outsiders. The Ndorobo tendency to flee in the face of danger to protect Self and the use of trickery to slip away from an enemy assault reflects the value placed on life. The Ndorobo rarely use any type of force against opposing out-groups so as to not offend the divine Creator in killing another. Cleverness and the use of 
tricks are highly valued because these offer a way of escape without threatening life force.

It is interesting to note the sin the divine is most annoyed with is ordinarily identified by the Ndorobo as murder. It is Enkai who gives life; therefore Enkai should be the only one to extinguish life. Murder is viewed as usurping the authority of the divine Creator, not an envious position by any Ndorobo. It is the obligation for respecting the existence and welfare of life force which necessitates the moral standard demanding all human life be esteemed and places it in a position of high ethical significance.

\section{Ethical Principle of Role Standards}

The social roles an individual is expected to assume are generally defined by olkuak (personality) and include rules for behaviour in kin relations. The conformity of individuals to role expectations is highly valued as an ethical principle. The individual has a strong need to belong, work and live cooperatively with others in the community. This sociocentric Self and the cultural provisions that sustain it are found in personality. Olkuak is a culturally encoded dogma transmitted from generation to generation as pragmatic, authoritative principles. It is considered a moral link giving the person the necessary rudder to steer into acceptable, culturally moral waters. When this link is severed the person is doomed to wander into all manner of social ills, become lost to himself and society, and suffer severe reprisals. A Ndorobo folktale of a prodigal son is an allegory meant to teach just such a concept. ${ }^{6}$

In the prodigal son narrative, a Ndorobo father dutifully instructed his two sons in the rules of Ndorobo society. One son refused to listen, disobeyed his father by inappropriate behaviour and left home. He found himself in dire straits without food or clothing soon after leaving his homeland. At this point, the son remembered in his misery the teaching of his father and realised all his trouble was caused by his refusal to submit his personality to community elders.

The only pathway to peace and well-being for the individual in life is through obedience and conformity. The narrative of the wayward son not only emphasises the submissive place of children towards their parents, but also represents individual standing in the community. The father symbolises the community, and the two sons represent individual members of the community. The identity of the person is Ndorobo; therefore, in order for the personality of the individual to become good and mature, the person must allow their personality to be shaped according to Ndorobo ideology. If not, prosperity is not possible.

The primary responsibility of teaching morality falls to family elders and 
secondarily to community elders. This is a serious responsibility that if ignored will lead to problematic relations. In a folktale of the father who spoils his eldest son, the boy is so disliked by his brothers that they plot to kill him. The father has failed to insist the boy conform to the traditional Ndorobo social role as an equal brother with equal responsibilities, and the son develops a bad personality. This is an extreme case in which a bad personality seems to be more unethical than murder. ${ }^{7}$

Every person has multiple social identities which interrelate with community Other by what Goodenough refers to as 'identity relationships' (1971:312). The significant defining criteria of social identities among the Ndorobo are age, gender, descent, and tribe. These social identities confer on identity relationships distinct duties, privileges, authority, obligations and impunities Self cannot escape. The identity relationships culturally recognised among Ndorobo may be divided into three social groups: (a) kin relationships, (b) community relationships, and (c) relationships with those outside community. For instance, a Ndorobo man uses his non-physical Self elements to elucidate his social identities as son, brother, age-mate, husband, father, community elder, Ndorobo tribal member, agropastoralist, Maa speaker, Kenyan, and an African black man. The personality element defines each of these identities and the social relationships particular to each distinctive identity; and then personality, conscience, character, and honesty bring awareness and obligation to properly abide by the principles governing each specific social identity and relationship. In addition, these components exert influence on the elements of emotion, desire, decision to conform to social propriety.

Failure by an individual to utilise olkuak in its intended social role as defining Self, community Other and earthly Other and accepting relationships on the basis of norms is a moral breach. All the elements of Self are held up to the social moral ideal. The role of sanctions and incentives by the social community in the behaviour of Ndorobo is extensive. In a group oriented society such as Ndorobo, the network of complex social relationships containing the opinions of kinsmen, age-mates, and elders wields a strong influence on the behaviour of the single person. The possibility of invoking shame, disgrace, betrayal, or dishonour as a result of behavioural indiscretion is a very real sanction in Ndorobo practice. It is ingrained in the moral consciousness and motivation of Ndorobo to behave in such a way so as to not bring disgrace or disdain to oneself and one's community.

The role of sanctions, incentives, and consequences in the explanation of behaviour should not imply Ndorobo recognise these as the sole reason for moral action. Doing that which is morally correct in order only and always to avoid sanctions or undesirable consequences is overstated. The element of desire 
(iyieunot) allows for a person to embrace Ndorobo personality out of respect for and acceptance of societal values. Desire becomes a moral will subservient to the moral ought of personality.

\section{Conclusion}

Four basic principles are fundamental codes of ethical conduct among the Ndorobo: Ethical principles of social unity, relational exchange, respect, and role standards. It is these social codes which distinguish man from the animal world. The Ndorobo believe their community is a moral society observing moral law by preserving social conventions.

The welfare and unity of the group is not and cannot be separated from the moral behaviour of individuals. This is not true of any animal species for each is driven by instinct alone. Animals possess life in the form of enkishui but do not possess the ability to make choices in life experience. Morality exists in humanity because of the free will of man to submit to or rebel against his in-group.

Relations between the individual and the community are a central concern for the Ndorobo. So central in fact that according to traditional Ndorobo medicine, there is a natural, intimate relationship between health and ethical behaviour. A motivational source which encourages the person to comply with the personality element is that the social, that is, the moral misconduct can cause physical and mental illness.

Ethical behaviour reciprocates by restoring physical and mental health. Thus the conceptions of health and illness allow a picture of what a normal individual is considered to be as defined by olkuak. Among the methods for preserving good health are: self control, sociability, unity of community relationships, generosity, distinguishing between natural and unnatural things, love in action through respect - all characteristics of a good olkuak. A person is morally evaluated according to their personality, whether good or bad. Personality, that is the nonphysical element of olkuak, is perhaps the most important ethical concept in Ndorobo world view.

\section{Endnotes}

${ }^{1}$ Ole Nkaru, personal communication, March 19, 1998.

${ }^{2}$ Simon Ngayami, personal communication, March 11, 1998.

${ }^{3}$ Ibid.

${ }^{4}$ Koseken Mebarni, personal communication, October 11, 1997.

${ }^{5}$ Enkishui is the non-physical Self element that is translated 'soul' but is also a synonym for 'life'. Enkishui is the most significant psychical element of man 
representing life force.

${ }^{6}$ Jackson Ngayami, personal communication, June 19, 1998.

${ }^{7}$ Putiai Krondo, personal communication, December 4, 1997.

\section{References}

Bird, F.1981, Paradigms and Parameters for the Comparative Study of Religious and Ideological Ethics, Journal of Religious Ethics, Vol. 9, No. 2. pp. 157-185

Durkheim, E., 1965, The Elementary Forms of the Religious Life, New York: Free Press.

Gbadegesin, S., 1991, African Philosophy, New York: Peter Lang.

Goodenough, W., 1971, Rethinking 'Status' and 'Role': Toward a General Model of the Cultural Organization of Social Relationships, In Nelson Graburn, ed., Readings in Kinship and Social Structure, New York: Harper \& Row. pp. 309-321.

Gyekye, K., 1987, An Essay on African Philosophical Thought: The Akan Conceptual Scheme, Cambridge, England: Cambridge University Press.

Kearney, M., 1996, Worldview, in D. Emberson and M. Ember, eds., Encyclopedia of Cultural Anthropology, Vol. 4, New York: Henry Holt. pp. 1380-1384. Malefijt, A., 1989, Religion and Culture: An Introduction to Anthropology of Religion, Prospect Heights, IL: Waveland.

Mbiti, J., 1990, African Religions and Philosophy, Oxford, England: Heinemann. Molema, S., 1920, The Bantu: Past and Present, Edinburgh, Scotland: Edinburgh University Press.

Moseley, J., 1979, Literature and Ethics: Some Possibilities for Religious Thought, Perspectives in Religious Studies, Vol. 6, No. 1, pp. 17-23.

Nwagwu, M. G., 2002, Religious Practices and Moral Behaviour in Africa, Asia Journal of Theology, Vol. 16, No.1, pp. 36-48.

Sarpong, P., 1972, Aspects of Akan Ethics, Ghana Bulletin of Theology, Vol. 4, No. 3, pp. 39-48.

Thiroux, J., 1977, Ethics: Theory and Practice, London: Collier Macmillan Publishers.

Uka, E. M., 1991, Ethics of African Traditional Religion, in E.M. Uka, ed., Readings in African Traditional Religion: Structure, Meaning, Relevance, Future, Bern, Switzerland: Peter Lang. pp. 180-194. 